\title{
FOREST EDGE EFFECTS ON SEEDLINGS IN MIXED ORIENTAL BEECH (Fagus orientalis Lipsky) - SCOTS PINE (Pinus sylvestris L.) STANDS
}

\author{
TOPAÇOĞLU, O. ${ }^{1 *}-$ GENÇ, E. ${ }^{2}$ \\ ${ }^{1}$ Kastamonu University, Faculty of Forestry, Kuzeykent, 37100 Kastamonu, Turkey \\ ${ }^{2}$ Samatlar Forest Directorate, Iğdir, Kastamonu, Turkey \\ (phone: +90-366-280-17-35; fax: +90-366-215-23-16) \\ *Corresponding author \\ e-mail: otopacoglu@kastamonu.edu.tr
}

(Received $15^{\text {th }}$ Nov 2018; accepted $11^{\text {th }}$ Jan 2019)

\begin{abstract}
Forest edges created by silvicultural treatment influence micro-climatic conditions and available light in forest stands. Studies regarding the impacts of forest edges on regeneration is limited in mixed Oriental beech (Fagus orientalis Lipsky)-Scots pine (Pinus sylvestris L.) stands. In this study, the influences of forest edges on height growth, root-collar-diameter growth and density of seedlings in an adjacent stand of Oriental beech-Scots pine were observed. In addition, the effects of stand basal area and height-to-crown on height growth, root-collar-diameter growth and seedlings density were monitored. The study was conducted within Samatlar Forest Planning Directorate, in Kastamonu city, Turkey. In the selected Oriental beech-Scots pine stand, twenty-five transects were installed perpendicular to the forest edge, and all the measurements were taken within these transects. There were statistically significant relationships between the distance from the forest edge and the growth of Scots pine seedlings $(p<0.05)$, while the stand edge did not have any effect on the growth of Oriental beech seedlings. Density of Scots pine seedlings decreased, while Oriental beech seedling density increased from the edge into the intact stand $(\mathrm{p}<0.05)$. Stand basal area and height-to-crown did not significantly change from the edge into the intact stand ( $p>0.05)$. The differences in seedling growth and seedling density between the two species can be associated with their dissimilar tolerance to shade. The initial results obtained in this study point out the importance of forest edges on the regeneration of Oriental beech and Scots pine seedlings. Data suggest that regeneration of mixed Oriental beech-Scots pine should be successful using group methods rather than traditional shelterwood method within entire stand.
\end{abstract}

Keywords: establishment, growth, regeneration, edge, silviculture

\section{Introduction}

Forest canopy structure plays an essential role in energy fluxes between the atmosphere and the land (Smith et al., 2008). Canopy structure influence understory light availability, soil temperature and moisture, soil nutrients and several other factors in a forest (Aussenac, 2000; Xue et al., 2011). Measurement of forest canopy structure is crucial for prediction of forest productivity and development (Smith et al., 2008). Forest canopy structure is manipulated by forest managers and landowners through silvicultural practices to modify understory growth conditions (Lhotka and Stringer, 2013). Seedlings respond to natural and anthropogenic disturbances by various ratio of growth and survival (Rubin et al., 2006). Silvicultural disturbances not only influence the understory environment of the treated area, but also the microclimatic conditions of the untreated adjacent forest areas by creating forest edges in between (Baker et al., 2016).

Forest edge effect is due to the separation of the interaction between two adjacent ecosystems with a sudden transition (Murcia, 1995). Forest edges include the edges 
formed by the forest roads, rivers, forestry practices and power lines, as well as the natural openings such as rocks (Meister, 2007). Silvicultural treatments usually create forest edges with an adjacent stand, and these edges influence micro-climatic conditions within the stand (Baker et al., 2016). Factors such as air temperature, air humidity, vapor pressure, soil moisture, soil physical and chemical properties and light intensity vary between the outer and inner parts of the forest edges (Lhotka and Stringer, 2013; Dovčiak and Brown, 2014; Wekesa et al., 2018). Thus, understanding of the edge effects is crucial in forest management and woodlands (Ouin et al., 2015). In order to quantify the spatial scale at which stands are affected, the depth of forest edge effects has been observed in several studies (Laurance, 2000; Ries et al., 2004; Lhotka and Stringer, 2013). Research shows that the edge effects can extend at least ten meter into the adjacent stand, and these differences usually disappear after the first fifty meters from the edge towards interior stand (Murcia, 1995).

Oriental beech (Fagus orientalis Lipsky) and Scots pine (Pinus sylvestris L.) are economically and ecologically important deciduous and conifer tree species with wide distribution areas in Turkey (Boydak et al., 2011; Atik, 2013). Vast acreage of mixed stands comprised of these tree species is also present in the country. The sustainability of these mixed forests is possible through the successful regeneration of these tree species. Oriental beech is known to be a shade tolerant species, while Scots pine is intolerant to shade (Kara, 2018a, 2018b). Mixed Oriental beech-Scots pine stands have been commonly managed using traditional shelterwood method in Turkey (Odabaş1 et al., 2004). Shelterwood systems are high-forest systems in which seedlings are established under the parent trees, and includes the systems of successive regeneration (Matthews, 1991). However, due to the differences in their tolerance to shade, group or group shelterwood methods are considered more appropriate to manage this forest type. With group methods, the group clearings or the groups with relatively lower density create edges with the intact stand. In general, Scots pine seedlings can be attained in groups, while Oriental beech is regenerated using traditional shelterwood method within the rest of the stands using relatively higher stand density. It is also likely to obtain Scots pine seedlings outside the groups and close to edges created. Studies comparing the edge of the forest with that of the inner forest have indicated that there is a higher amount of light on the forest edge, and it usually increases tree growth and the density of understory plants at or near the edges (Gehlhausen et al., 2000; Lhotka and Stringer, 2013). However, our knowledge on the influence of forest edge, and its extend on mixed Oriental beech-Scots pine stands is limited.

Several studies have explored the effects of forest edges on understory plants within interior parts of stands (Jiquan Chen et al., 1992; Gehlhausen et al., 2000; Burton, 2002; Hamberg et al., 2009; Gatti et al., 2019). However, to improve our understanding regarding the forest edges, it has been stated that more research on the forest edges is need for different forest types in different regions (Š́lek et al., 2013). To our knowledge, no such study has been conducted in mixed Oriental beech-Scots pine stands. Moreover, recently, there has been a growing concern by Turkish forester on the decreasing proportion of Scots pine trees in the mixed beech-pine stands, which would result in the conversion of these mixed stands into pure beech stands in Turkey. Thus, understanding of the forest edges in these forests will help forest managers develop more appropriate management practices for the sustainability of these mixed forests in Turkey. The determination of the edge effects will help improve the success of group methods when naturally regenerating these mixed forests types as well. Understanding 
of the forest edges effects on the Oriental beech and Scots pine seedlings is essential for the sustainability of mixed stands of these tree species. Therefore, in this study, the influences of forest edges on the seedling density $\left(\mathrm{ha}^{-1}\right)$, height growth $(\mathrm{cm})$ and rootcollar diameter growth $(\mathrm{mm})$ of Oriental beech and Scots pine seedlings in a mixed stand were observed. It is also aimed to examine how far the edge effect is from the edge of the stand to the interior stand. Moreover, the effects of stand basal area $\left(\mathrm{m}^{2} \mathrm{ha}^{-1}\right)$ and height-to-crown on the height growth and root-collar-diameter growth of seedlings of both species, when moving from the edge to interior stand, were monitored.

\section{Materials and Methods}

\section{Study area}

This study was conducted in a mixed Oriental beech-Scots pine forest managed by Samatlar Forest Directorate, within the boundary of Kastamonu Forest Regional Directorate in Kastamonu, Turkey (Figure 1). The study area was located within the compartment 90 . Total forested area is 49.149 ha, which is approximately $74 \%$ of the entire area within Samatlar Forest Directorate. Kastamonu is situated in the EuroSiberian fito geographic region (Çolak et al., 2009). Study area is located within the natural range of Oriental beech and Scots pine species. In addition to Oriental beech and Scots pine, black pine (Pinus nigra subp. pallasiana), Calabrian pine (Pinus brutia), Trojan fir (Abies equi-trojani), juniper (Juniperus sp.), oaks (Quercus sp.) and hornbeam (Carpinus sp.) are other tree species of the region. Blackberry (Rubus spp.), rockrose (Cistus laurifolius), heath (Erica sp.), cranberry (Cornus sp.) and ferns (Pteridium aquilinum) are the common understory species within study region. Average altitude of the study area is 1340 meter above the sea level, and average slope ranges from 10 to $30 \%$ across the study area. Study area is in the transition zone between Anatolian terrestrial and Black Sea temperate climates, therefore, cold/wet winters and rainy/wet summers occur in the region. The average annual temperature is $10.9^{\circ} \mathrm{C}$ within the study area ranging between -1.1 and 26.6. The average annual precipitation is $570 \mathrm{~mm}$ ranging from 250 to $689.5 \mathrm{~m}$ in the last twenty years. In the study region, the vegetation period lasts approximately 137 days starting from late April through later August. Sandy clay and loamy-clay soils are usually examined in the study region. The dominant soil group is mostly brown calcareous in the study region.

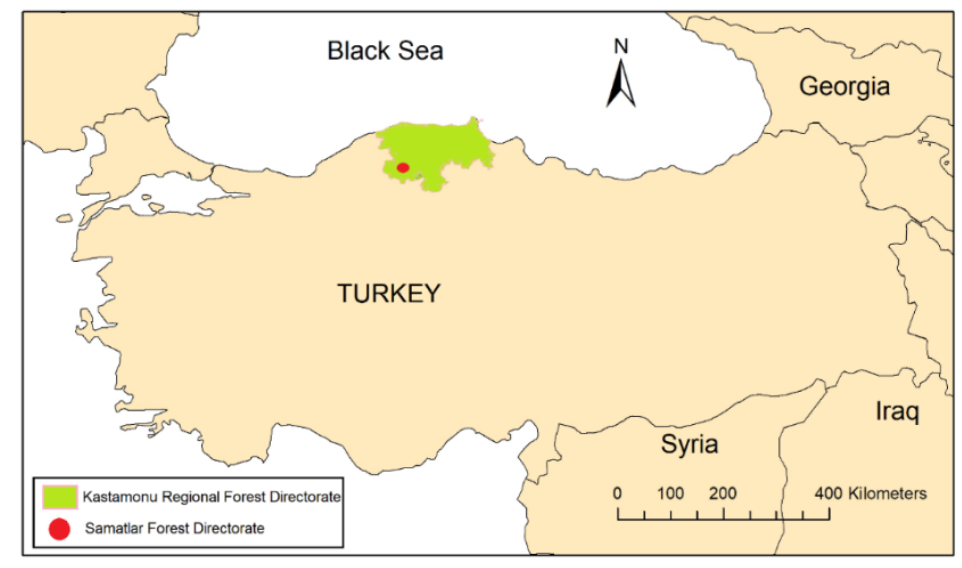

Figure 1. Boundary of Kastamonu Regional Forest Directorate, and location of study area 


\section{Study Design}

The study was established along a mixed Oriental beech-Scots pine forest matrix that surrounded a forest opening of approximately 0.3 ha in size (Figure 2) in the spring of 2016. The study site is located at Longitude of 33.167075, and Latitude of 41.302296. About $90 \%$ of the stand basal area $\left(\mathrm{m}^{2} \mathrm{ha}^{-1}\right)$ composed of Oriental beech and Scots pine trees. The opening has been untreated to serve as a foot plot for wildlife animals for a prolonged time. The stand has been managed using the traditional shelterwood method. The topography of the opening was relatively flat, with a slope less than $10 \%$. This study used the edge environment around a forest opening to examine whether distance from the edge affected the root-collar-diameter growth and height growth of Oriental beech and Scots pine seedlings in a mixed stand of these tree species.

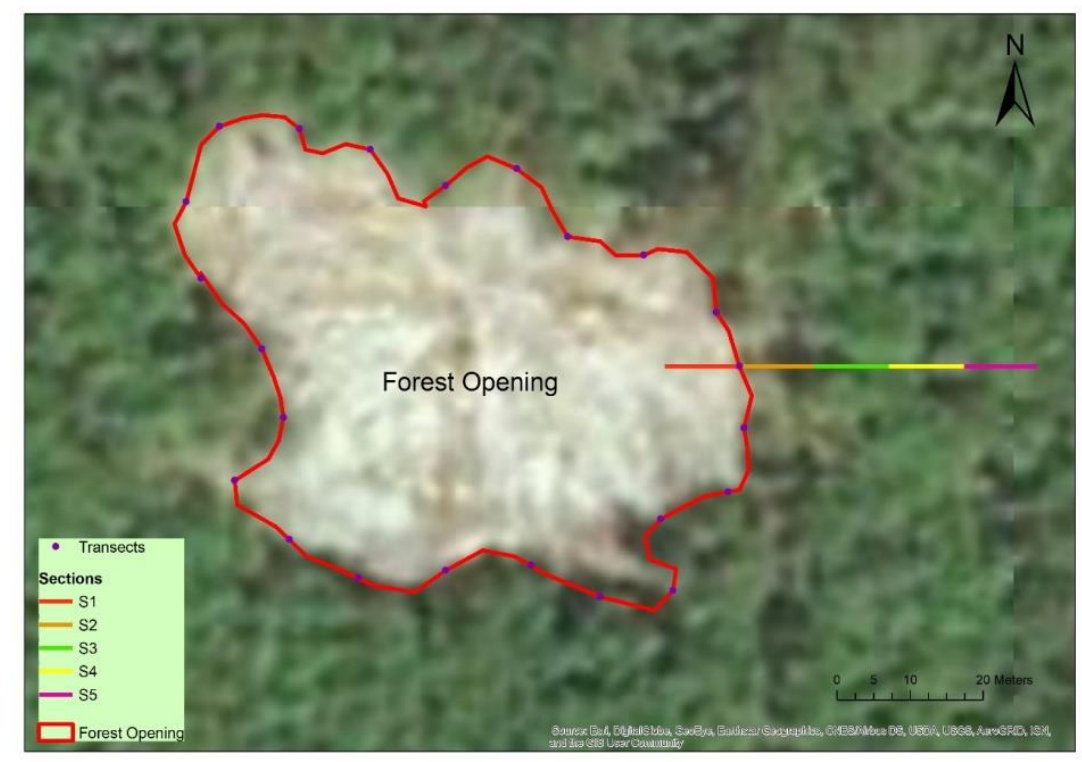

Figure 2. Study area and a sample transect

As suggested by Lhotka and Stringer (2013), the stand edge was determined as the border between the two nearest trees growing along the boundary of the forest opening. First, twenty-five sampling locations were chosen every ten meter along the perimeter of the forest opening (Figure 2) in the spring of 2016. Next, at each sampling location, twenty-five transects were installed perpendicular to the forest edge, and they extended 10 meter from the edge into the opening, and 40 meter from the edge into the stand (Figure 2). The width of transects was 1 meter, and there was not any canopy gaps along transects. Moreover, due to a recent understory control treatments, there was not any other species rather than Oriental beech and Scots pine understory of the study stand.

\section{Measurements and Analysis}

Measurements were taken in the summer (July and August) of 2016. Each transect was divided into five sections; one section within the opening (S1) and four sections within the stand (i.e., S2, S3, S4 and S5 for intervals of 0-10, 10-20, 20-30 and 30-40 m, respectively). In each section, all trees larger than $5 \mathrm{~cm}$ in diameter at breast height 
(d.b.h.) were measured. Using the d.b.h. measurements, basal area of each tree was determined using the formula below, and then, it was converted to basal area per hectare.

$$
\text { Tree basal area }=\mathrm{d} . \mathrm{b} . \mathrm{h}^{2}(0.0000785)
$$

Number of seedlings for each species was counted in each section, and it was converted to calculate number of seedlings for unit area (i.e., one ha). Within each section, five-year old Oriental beech and Scots pine seedlings were individually selected in 2017. It should be noted that seedlings' age were determined by counting the whorls following DeYoung (2016). Small single branches between major whorls were not included when counting age as suggested (DeYoung, 2016). Root-collar-diameter (mm) of selected seedlings was measured with a digital caliper to monitor total root-collardiameter growth of seedlings of both species over five-year period. For each seedling, one root-collar-diameter measurement was taken first, and next, the second measurement, which was perpendicular to the first one, was conducted. Two measurements were averaged to attain the root-collar-diameter of each seedling.

In addition, height $(\mathrm{cm})$ of selected seedlings was determined with a ruler to attain the total height growth of seedlings at age five. Distance $(\mathrm{m})$ of each selected seedlings to the edge border was measured using a measuring tape height-to-crown, which refers to the vertical distance $(\mathrm{m})$ from the surface to the first living branch of tree (Lhotka and Loewenstein, 2008), was measured every two meter in each section with a TruPulse Laser Rangefinder (Laser Tech Inc.). Height-to-crown measurements taken in each section were averaged to obtain average height-to-crown for each section.

Lhotka and Stringer (2013) stated that the study design used in this study is not manipulated by nature, thus, each transect can be treated as "replicate" because they are treated identically. Thus, there was 25 replicates of edge effects in this study. Rootcollar-diameter of seedlings at age five were averaged for each categorized distance intervals (i.e., sections). Same procedure was repeated for seedling height for each section. Log-transformation was utilized for five-year root-collar-diameter growth and height growth data to enhance residual homogeneity and normality (Mcdonald, 2013).

Mixed-effect Analysis of Variance (ANOVA) model of was utilized to define the relationships between the distance from the edge and seedling root-collar-diameter and height growth $(\alpha=0.05)$. The test incorporated the transects as as random effect, while the distance from the edge was treated as fixed effect. The "lmer" function of "nlme" package in R-Statistical software (R Development Core Team, 2010) was used for this analysis. Tukey's pairwise comparison method for testing statistical significance of seedling density, root-collar-diameter and height growth among the categorized distance intervals (i.e., sections) was used $(\alpha=0.05)$. The categorized distance intervals (i.e., sections) were the experimental units for the mixed-effect ANOVA model as suggested (Lhotka and Stringer, 2013). In addition, the influences of the distance from the edge on the number of seedlings was found using poisson regression with the "glmer" funtion in R-Statistical software, since this test is recommended for the count data such as number of seedlings per hectare. Moreover, the influences of stand basal area and height-tocrown on the total root-collar-diameter growth and total height growth of seedlings over five years were determined using the mixed-effect linear regression method for each species, in which the transect was incorporated as as random effect, while basal area and height-to-crown were treated as fixed effects. The "lme" function of "nlme" 
package in R-Statistical software (R Development Core Team, 2010) was used for this analysis. Normality and homogeneity of variance were tested with residual analysis. RStatistical software (R Development Core Team, 2010) was utilized for all statistical analyses.

\section{Results and Discussion}

\section{Canopy Structure}

Stand basal area and height-to-crown were measured to examine canopy structure across transects. Basal area ranged from 4.73 to $65-\mathrm{m}^{2} \mathrm{ha}^{-1}$ across all transects (Table 1). Tukey's pairwise comparison test showed that there was not significant differences between S2-S3 ( $\mathrm{p}=0.99$ ), $\mathrm{S} 2-\mathrm{S} 4$ ( $\mathrm{p}=0.99), \mathrm{S} 2-\mathrm{S} 5$ ( $\mathrm{p}=0.92), \mathrm{S} 3-\mathrm{S} 4(\mathrm{p}=0.99), \mathrm{S} 3-\mathrm{S} 5$ ( $\mathrm{p}=$ $0.85)$ and $\mathrm{S} 4-\mathrm{S} 5(\mathrm{p}=0.59)$ pairs in terms of stand basal area. Due to few trees within $\mathrm{S} 1$, basal area was lower in this section. Basal area of S1, which was located inside the opening, was significantly different from the basal areas of sections located inside the stand (i.e., S2, S3, S4 and S5) ( $\mathrm{p}<0.05)$. Even though not statistically significant ( $>>0.05)$, the furthest section from the edge (i.e., S5) had relatively lower basal area $\left(26.67 \mathrm{~m}^{2} \mathrm{ha}^{-1}\right)$ than the other sections located interior stand (i.e., $32.33,32.89$ and 35.47 $\mathrm{m}^{2} \mathrm{ha}^{-1}$ for $\mathrm{S} 2, \mathrm{~S} 3$ and $\mathrm{S} 4$, respectively). This is likely due to the decreasing amount of light from the edge towards to interior stand.

Our findings on the basal area among the sections seem to be consistent with previous studies. Previous researches, which compared the edge of the forest with that of the inner forest, have found out that there were higher amount of light close to the forest edge, and it usually increased tree growth at or near the edges (Gehlhausen et al., 2000; Lhotka and Stringer, 2013). It has been also stated that amount of light in openfield conditions is usually higher than it is inside forests (Heithecker and Halpern, 2007), as we observed in this study. We found that basal area started to decrease in S5 that is at least $30 \mathrm{~m}$ away from the edge suggesting that forest edge had influence on overstory trees within $30 \mathrm{~m}$ range from the edge into the intact forest in Oriental beechScots pine forests. This is also supported with previous studies such as Heithecker and Halpern (2007), and Lhotka and Stringer (2013) since they revealed that the edge effects could extend 10-30 $\mathrm{m}$ into the adjacent stand.

Table 1. Descriptive statistics for basal area $\left(\mathrm{m}^{2} \mathrm{ha}^{-1}\right)$ and height-to-crown $(\mathrm{m})$. SD refers to the standard deviation of the variables

\begin{tabular}{c|c|c|c|c}
\hline Variables & Min. & Max. & Mean & SD \\
\hline Basal area & 4.7 & 65 & 31.6 & 17.9 \\
Height-to-crown & 0.7 & 17.2 & 6.99 & 3.34 \\
\hline
\end{tabular}

Height-to-crown was ranged from 0.7 to $17.2 \mathrm{~m}$ across all transects in Oriental beech- Scots pine forests (Table 1). There was not statistically significant relationships among sections in terms of height-to-crown $(\mathrm{p}=0.218, \mathrm{~F}=1.476)$, that is, height-tocrown did not significantly change from the open field conditions to the interior stand. Tukey's pairwise comparison test showed that there was not any significant differences between S2-S3 ( $\mathrm{p}=0.63), \mathrm{S} 2-\mathrm{S} 4$ ( $\mathrm{p}=0.88), \mathrm{S} 2-\mathrm{S} 5$ ( $\mathrm{p}=0.74), \mathrm{S} 3-\mathrm{S} 4$ ( $\mathrm{p}=0.98), \mathrm{S} 3-\mathrm{S} 5$ ( $\mathrm{p}=$ $0.99)$ and $\mathrm{S} 4-\mathrm{S} 5(\mathrm{p}=0.99)$ pairs in terms of height-to-crown. When comparing heightto-crown among sections, we attained the lowest height-to-crown $(3.85 \mathrm{~m})$ in $\mathrm{S} 1$, which 
was located inside the opening. Average height-to-crowns were 6.02, 7.68, 7.10 and $7.43 \mathrm{~m}$ for S2, S3, S4 and S5, respectively. This is likely because the trees inside the forest opening have grown under open-grown conditions and deprived of self-pruning, and consequently, developed branches that are lower to the ground. In a similar study, Lhotka and Stringer (2013) monitored the changes in the canopy height (i.e., height-tocrown) from open-field conditions into the intact forest in a mixed deciduous forest, and discovered that height-to-crown was lowest inside the opening, and did not significantly change from edge into the stand. Given the findings in the literature, our findings regarding stand basal area and vertical canopy structure seem to be logical.

\section{Seedling Density}

The number of Oriental beech seedlings increased from open field conditions into the intact forest (Table 2). There was a statistically significant relationships between number of Oriental beech seedlings and distance to the stand edge $(\mathrm{p}<0.001)$. However, Tukey's pairwise comparison test showed that there was not any significant differences between S2-S3 $(p=0.98)$ and $\mathrm{S} 4-\mathrm{S} 5(\mathrm{p}=0.97)$ pairs in terms of number of Oriental beech seedlings per ha. In other words, only the number of Oriental beech seedlings in $\mathrm{S} 1$, which was located inside the opening, was significantly different from the sections located inside the stand (i.e., S2, S3, S4 and S5) ( $<<0.05)$. Increasing density of Oriental beech towards into the intact stand could be associated with Oriental beech's tolerance to shade, since this species can survive under overstory trees for a prolonged time (Odabaş1 et al., 2004). Previous research has showed that Oriental beech seedlings can establish better under canopy than open-field conditions (Szwagrzyk et al., 2001; Parhizkar et al., 2011). Parhizkar et al. (2011) examined the effects of varying light intensities on Oriental beech stands, and reported that there was no significant differences in seedling density across the light intensities at age five. Stand basal area and height-to-crown had no significant effect on the density of Oriental beech seedlings $(\mathrm{p}>0.05)$.

Table 2. Average number of seedlings per hectare for each species in each section

\begin{tabular}{c|c|c}
\hline Sections & Oriental beech & Scots pine \\
\hline S1 & 400 & 7160 \\
S2 & 5040 & 4080 \\
S3 & 5320 & 1880 \\
S4 & 7560 & 1240 \\
S5 & 7720 & 680 \\
\hline
\end{tabular}

Contrary to Oriental beech, the number of Scots pine seedlings decreased from openfield conditions towards to interior stand (Table 2). There was a statistically significant relationships between number of Scots pine seedlings and distance to the stand edge $(\mathrm{p}=0.001)$. It was likely that light transmittance through canopy decreased from openfield conditions to interior stand. Therefore, data showed the importance of light for Scots pine existence, which is an intolerant species to shade (Barbeito et al., 2009). Moreover, it is likely that Scots pine seedling could not compete with Oriental beech seedlings for light and nutrients under the shade of overstory trees. Previous research have explored the influence of light on the presence of Scots pine seedlings under forest canopy, substantiating the decreasing number of Scots pine seedlings attained in deeper 
part of the stand (Barbeito et al., 2009; Pardos et al., 2007). Stand basal area had no significant effect on the density of Scots pine seedlings either $(\mathrm{p}>0.05)$.

\section{Seedling Growth}

Average height growth of Oriental beech seedlings ranged from 9.5 to $178 \mathrm{~cm}$ with an average of $78.34 \mathrm{~cm}$, while root-collar-diameter growth ranged between 1.65 and $20.8 \mathrm{~mm}$ (average $10.52 \mathrm{~mm}$ ) across all sections over five year period. In a similar study conducted in Iran, it was concluded that average seedling height and root-collardiameter growth were $67.85 \mathrm{~cm}$ and $10.56 \mathrm{~mm}$, respectively (Abkenar and Keshavarz, 2005). Parhizkar et al. (2011) monitored the influence of varying light intensities on Oriental beech seedlings, and found that average seedling growth ranged from 57.3 to $150 \mathrm{~cm}$, while root-collar-diameter ranged from 8 to $19 \mathrm{~mm}$. Our findings also fall between the ranges presented by Parhizkar et al. (2011). The distance from the stand edge did not any statistically significant influence on the height growth of Oriental beech seedlings following five year period $(\mathrm{p}=0.12)$ (Figure 3). Average height of Oriental beech seedlings did not significantly change from open-field conditions into the intact stand. In addition, there was not any statistically significant relationships between the root-collar-diameter growth of Oriental beech seedlings and the distance from the stand edge $(\mathrm{p}=0.25)$ (Figure 3). Moreover, stand basal area had no significant influence on the height growth $(\mathrm{p}=0.08)$ and root-collar-diameter growth $(\mathrm{p}=0.13)$ of Oriental beech seedlings over five year period. Height-to-crown did not significantly affected the height growth $(\mathrm{p}=0.6)$ and root-collar-diameter growth $(\mathrm{p}=0.09)$ of Oriental beech seedlings either.
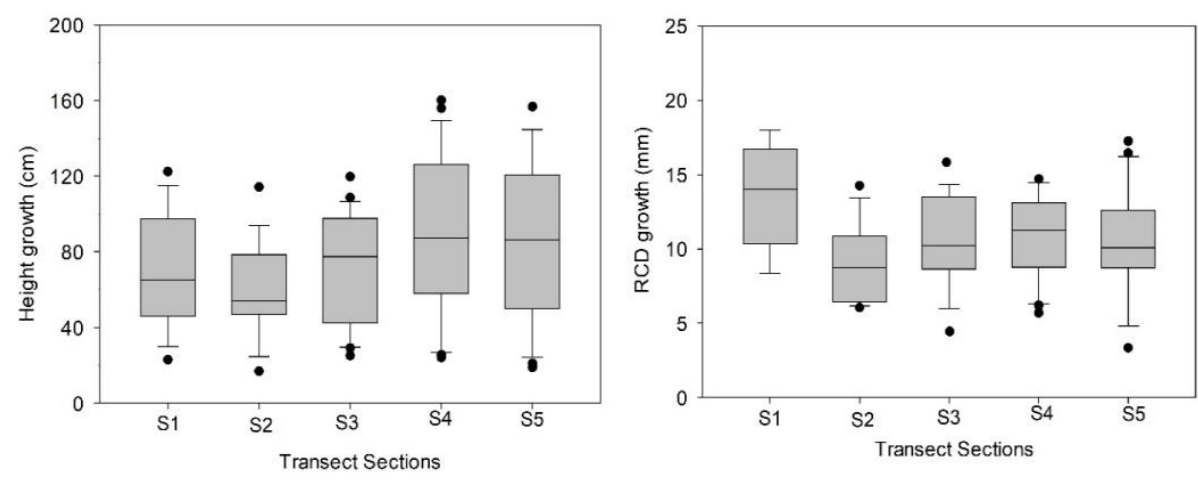

Figure 3. The means of the height and root-collar-diameter $(R C D)$ growth of Oriental beech seedlings under varying distances to the stand edge. Bars represent the standard deviations for the amounts of needle removal while the dots indicate the potential outliers

The mean seedling height was 43.86 ranging from 13.3 to $98.85 \mathrm{~cm}$ for Scots pine seedlings, while root-collar-diameter growth ranged between 4.35 and $26.5 \mathrm{~mm}$ (average $10.03 \mathrm{~mm}$ ) across all sections at age five. The growth rates of Scots pine seedlings observed in this study were consistent with previous studies. In a study conducted in Sweden, it was found that Scots pine seedlings planted under a canopy reach an average height of $40 \mathrm{~cm}$ at the end of the five growing seasons (Egnell and Valinger, 2003). In a different study, which monitored the effects of varying stand density on root-collar-diameter growth of Scots pine seedlings, an average of $13 \mathrm{~mm}$ in root-collar-diameter was determined (Gerelbaatar et al., 2015). The distance from the 
stand edge had statistically significant effect on the height growth of Scots pine seedlings following five year period $(\mathrm{p}=0.0001)$ (Figure 4). Average height of Scots pine seedlings decreased with increasing distance from the stand edge. In addition, there was statistically significant inverse relationships between the root-collar-diameter growth of Scots pine seedlings and the distance from the stand edge $(\mathrm{p}=0.001)$ (Figure 4). Moreover, since stand basal area did not significantly change from the edge into the stand, it had no significant effect on the height growth and root-collar-diameter growth ( $p>0.05$ ) of Scots pine seedlings over five year period. Height-to-crown had also no significant effect on the height growth and root-collar-diameter growth $(p>0.05)$ of Scots pine seedlings.
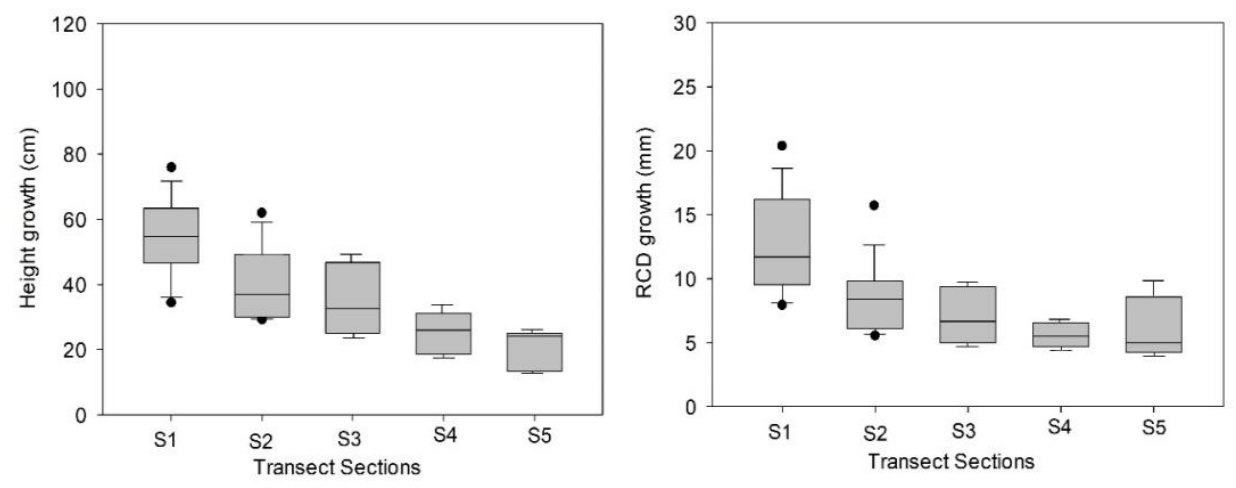

Figure 4. The means of the height and root-collar-diameter (RCD) growth of Scots pine seedlings under varying distances to the stand edge. Bars represent the standard deviations for the amounts of needle removal while the dots indicate the potential outliers

Understanding of the relationship between edge effects and seedling growth is essential for the establishment of understory seedlings when natural regeneration is aimed. Forest edges affect the understory light environment (Lhotka and Stringer, 2013). This study support the notion that the amount of light under the forest canopy affect seedling growth of intolerant tree species such as Scots pine. Even though stand density (i.e., basal area) and height-to-crown did not significantly change from the stand edge into the stand, Scots pine seedling growth significantly decreased towards interior stand. Thus, the decreasing seedling growth from the edge into the stand can be associated with the edge effect. Our finding suggests that forest edge was effective for light environment, within $40 \mathrm{~m}$ from edge, in Oriental beech- Scots pine forests. In previous research, Carus (2004) and Pardos et al. (2007) also found out that understory light is usually the most limiting factor which influence the growth of Scots pine seedlings. In a similar study, Gerelbaatar et al. (2015) examined the growth of Scots pine seedlings under varying intensities, and found higher seedling growth under higher light intensity.

The opposite pattern in Oriental beech seedlings (i.e., increasing growth of seedlings from the edge into the stand) may be related to its competition with Scots pine seedlings. Scots pine seedlings are more light-demanding species than Oriental beech seedlings. Thus, under open-field conditions, Scots pine seedlings' rapid growth likely suppressed Oriental beech seedlings, and became denser. On the other hand, Scots pine seedlings could not compete with Oriental beech seedlings interior stand due to lower amount of light, therefore, Oriental beech seedlings had more growing space and 
nutrients inside stand, and presented higher density. Data suggested that decreasing light through the edge effects did not have any negative influence on the growth of Oriental beech forests. Similarly, Abkenar and Keshavarz (2005) observed the height growth of Oriental beech seedlings under canopy and in canopy opening, and found that seedling growth did not significantly differ between the two conditions. In another study, Parhizkar et al. (2011) observed the growth of Oriental beech seedlings under varying light intensities, and revealed that there was not any relationship between light intensity and seedling growth. Given the data in previous research, our findings regarding Oriental seedling growth seem to be acceptable.

Traditional shelterwood method has been widely used in Oriental beech-Scots pine forests in Turkey Odabaşı et al. (2004), including the study area. Approximately 50007000 seedlings per ha at age five for each species are recommended for natural regeneration of these forests in this method (Odabaş1 et. al., 2004; Calama et al., 2015). Given these numbers in the literature, our data showed that there was insufficient number of Scots pine seedlings when moving more than $10 \mathrm{~m}$ from the edge into the stand in the study stand. Therefore, the results suggest that shelterwood method within the entire area may be unsuccessful in these forests. Instead, Scots pine seedlings could be obtained in open-field conditions and near the edges. Groups could be created with complete clearing of vegetation, or using group shelterwood with a canopy closure of $40 \%$ in this stand type in favor of Scots pine (Odabaş1 et. al., 2004). Data also showed that adequate number of Oriental beech seedlings could be obtained under the shade of overstory seedlings, thus, any partial cutting such as shelterwood or singletree selection methods outside the groups may be successful for the natural regeneration of Oriental beech in these stands. Mean height and root-collar-diameter growth of Scots pine seedlings after $10 \mathrm{~m}$ from the edge were lower that what observed in previous studies (Egnell and Valinger, 2003; Gerelbaatar et al., 2015) (Figure 4), that is, stand edge has negative effects on Scots pine seedlings after $10 \mathrm{~m}$ from the edge. Therefore, the size and number of groups when conducting group methods should be decided taking the range of edge effects (i.e., 10-40 m) into account in mixed Oriental beech-Scots pine stands.

\section{Conclusions}

This study presented the relationships between the distance from stand edge and growth of Scots pine seedling, while no effect of the edge on Oriental beech seedlings was observed. Data showed that the edge effect on Scots pine seedlings was present after $10 \mathrm{~m}$ from the edge into stand, and may extend up to $40 \mathrm{~m}$ into the stand adjacent to a forest opening. Study results add knowledge to the scientific understanding of the edge effects in mixed Oriental beech-Scots pine stands. Initial results suggest that Scots pine seedling can be established in canopy gaps or group clearing, while Oriental beech should be successfully attained under canopy within the rest of the stands. Traditional shelterwood method has been commonly used to regenerate mixed Oriental beech-Scots pine stands in Turkey; however, our results indicate that Scots pine seedlings may not well develop under overstory trees, and the stands may turn into pure stands of Oriental beech in long term. The influence of edges created by silvicultural treatments should be taken into account when group methods are aimed in this forest type. The data presented in this study will be helpful for forest managers who aim to enhance seedling development and establishment in mixed Oriental beech-Scots pine forests. However, 
more research should be conducted on the use of group selection method in the mixed Oriental beech-Scots pine stands. In addition, this study was conducted on a single forest opening; thus, forest edge effects along varying gap sizes should be considered in the future studies. Moreover, direct light measurements thorough the sections of the lines should be taken in further research. We also stated that there has been a growing concern on the decreasing proportion of Scots pine trees in the mixed beech-pine stands and other mixed stands that contain Scots pine; therefore, similar studies should be conducted in mixed stands of Scots pine and other tree species such as oak (Quercus), fir (Abies) and spruce (Picea) in Turkey.

\section{REFERENCES}

[1] Abkenar, K. T., Keshavarz, M. (2005): Influence of light condition on quality and quantity characteristics of beech (Fagus orientalis lipsky) sapling in north of Iran. - Asian Journal of Plant Sciences 4(3): 261-263.

[2] Atik, A. (2013): Effects of Planting Density and Treatment with Vermicompost on the Morphological Characteristics of Oriental Beech (Fagus orientalis Lipsky.). - Compost Sci. Util. 21: 87-98.

[3] Aussenac, G. (2000): Interactions between forest stands and microclimate: Ecophysiological aspects and consequences for silviculture. - Ann. For. Sci. 57: 287-301.

[4] Baker, T. P., Jordan, G. J., Baker, S. C. (2016): Microclimatic edge effects in a recently harvested forest: Do remnant forest patches create the same impact as large forest areas? - For. Ecol. Manage. 365: 128-136.

[5] Barbeito, I., Fortin, M. J., Montes, F., Cañellas, I. (2009): Response of pine natural regeneration to small-scale spatial variation in a managed Mediterranean mountain forest. - Appl. Veg. Sci. 12: 488-503.

[6] Boydak, M., Ertaş, A., Çalışkan, S. (2011): Eskişehir -Çatacık yöresi sarıçamlarında (Pinus sylvestris L.) tohum verimi. - Journal of the Faculty of Forestry, Istanbul University 61(2): 17-37.

[7] Burton, P. J. (2002): Effects of clearcut edges on trees in the sub-boreal spruce zone of Northwest-Central British Columbia. - Silva Fennica. 36(1): 329-352.

[8] Calama, R., Manso, R., Barbeito, I., Madrigal, G., Garriga, E., Gordo, F. J., Montero, G., Cañellas, I., Pardos, M. (2015): Do inter-specific differences in seed size determine natural regeneration traits in pinus pinea and pinus sylvestris? - Appl. Ecol. Environ. Res. 13(2): 387-404.

[9] Carus, S. (2004): Increment and growth in timberline Scotch pine (Pinus sylvestris L.) stands at Ilgaz Mountain, Turkey. - Pakistan Journal of Biological Sciences 7(2): 212218.

[10] Chen, J., Franklin, J. F., Spies, T. A. (1992): Vegetation responses to edge environments in old-growth Douglas-fir forests. - Ecol. Appl. 2(4): 387-396.

[11] Çolak, A. H., Tokcan, M., Rotherham, I. D., Atici, E. (2009): The amount of coarse dead wood and associated decay rates in forest reserves and managed forests, northwest Turkey. - Investigación Agraria: Sistemas y Recursos Forestales 18(3): 350-359.

[12] DeYoung, J. (2016): Forest Measurements: An Applied Approach. - Open Oregon Educational Resources. 167 p.

[13] Dovčiak, M., Brown, J. (2014): Secondary edge effects in regenerating forest landscapes: vegetation and microclimate patterns and their implications for management and conservation. - New forests 45(5): 733-744.

[14] Egnell, G., Valinger, E. (2003): Survival, growth, and growth allocation of planted Scots pine trees after different levels of biomass removal in clear-felling. - For. Ecol. Manage. 177: 65-74. 
[15] Gatti, M. G., Zaninovich, S. C., Vespa, N. I., Zurita, G. A. (2019): Moving away from the native forest edge: Changes in ecosystem processes towards the interior of Pinus taeda plantations. - Forest Ecology and Management 432: 967-975.

[16] Gehlhausen, S. M., Schwartz, M. W., Augspurger, C. K. (2000): Vegetation and microclimatic edge effects in two mixed-mesophytic forest fragments. - Plant Ecol. 147(1): 21-35.

[17] Gerelbaatar, S., Baatarbileg, N., Batsaikhan, G. (2015): Density and growth performance of Scots pine (Pinus sylvestris L.) understory saplings in logged forests of Tujiin Nars National Park in the Western Khentii Mountains: Case study from Northern Mongolia. Glob. Adv. Res. J. Agric. Sci. 4(1): 017-025.

[18] Hamberg, L., Lehvävirta, S., Kotze, D. J. (2009): Forest edge structure as a shaping factor of understorey vegetation in urban forests in Finland. - For. Ecol. Manage. 257: 712-722.

[19] Heithecker, T. D., Halpern, C. B. (2007): Edge-related gradients in microclimate in forest aggregates following structural retention harvests in western Washington. - For. Ecol. Manage. 248: 163-173.

[20] Kara, F. (2018a): Silvicultural management tool for the Oriental beech (Fagus orientalis Lipsky) forests. - Journal of Sustainable Forestry 37(4): 403-413.

[21] Kara, F. (2018b): A Stocking diagram for silvicultural implications in Scots Pine (Pinus sylvestris L.) stands. - Kastamonu Univ., Journal of Forestry Faculty 18(1): 53-61.

[22] Laurance, W. F. (2000): Do edge effects occur over large spatial scales? - Trends Ecol. Evol. 15(4): 134-135.

[23] Lhotka, J. M., Loewenstein, E. F. (2008): An examination of species-specific growing space utilization. - Can. J. For. Res. 38: 470-479.

[24] Lhotka, J. M., Stringer, J. W. (2013): Forest edge effects on Quercus reproduction within naturally regenerated mixed broadleaf stands. - Can. J. For. Res. 43: 911-918.

[25] Matthews, J. D. (1991): Silvicultural systems. - Oxford University Press.

[26] Mcdonald, J. H. (2013): Handbook of Biological Statistics, 3rd edition. - Sparky House Publishing. https://doi.org/10.1017/CBO9781107415324.004.

[27] Meister, R. (2007): Gestaltung und Pflege von Waldrändern. - Landwirtschaftskammer Österreich, Mauerbach.

[28] Murcia, C. (1995): Edge effects in fragmented forests: implications for conservation. Trends Ecol. Evol. 10(2): 58-62.

[29] Odabaşı, T., Calıskan, A., Bozkus, H. F. (2004): Silvikültür Tekniği. - Istanbul University Publications. Publication no: 4459. Istanbul, $314 \mathrm{p}$.

[30] Ouin, A., Cabanettes, A., Andrieu, E., Deconchat, M., Roume, A., Vigan, M., Larrieu, L. (2015): Comparison of tree microhabitat abundance and diversity in the edges and interior of small temperate woodlands. - Forest Ecology and Management 340: 31-39.

[31] Pardos, M., Montes, F., Aranda, I., Cañellas, I. (2007): Influence of environmental conditions on germinant survival and diversity of Scots pine (Pinus sylvestris L.) in central Spain. - Eur. J. For. Res. 126: 37-47.

[32] Parhizkar, P., Sagheb-Talebi, K., Mataji, A., Nyland, R., Namiranian, M. (2011): Silvicultural characteristics of Oriental beech (Fagus orientalis Lipsky) regeneration under different RLI and positions within gaps. - Forestry 84: 177-185.

[33] R Development Core Team. (2010): R: A language and environment for statistical computing. - R Foundation for Statistical Computing, Vienna, Austria.

[34] Ries, L., Fletcher, R. J., Battin, J., Sisk, T. D. (2004): Ecological responses to habitat edges: Mechanisms, models, and variability explained. - Annu. Rev. Ecol. Evol. Syst. 35: 491-522.

[35] Rubin, B. D., Manion, P. D., FaberLangendoen, D. (2006): Diameter distributions and structural sustainability in forests. - For. Ecol. Manage. 222: 427-438.

[36] Šálek, L., Zahradník, D., Marušák, R., Jeřábková, L., Merganič, J. (2013): Forest edges in managed riparian forests in the eastern part of the Czech Republic. - Forest ecology and management 305: 1-10. 
[37] Smith, M. L., Anderson, J., Fladeland, M. (2008): Forest canopy structural properties. In: Hoover, C. M. (ed.) Field measurements for forest carbon monitoring (pp. 179-196). Springer, Dordrecht.

[38] Szwagrzyk, J., Szewczyk, J., Bodziarczyk, J. (2001): Dynamics of seedling banks in beech forest: Results of a 10-year study on germination, growth and survival. - For. Ecol. Manage. 141(3): 237-250.

[39] Wekesa, C., Maranga, E. K., Kirui, B. K., Muturi, G. M., Gathara, M. (2018): Interactions between native tree species and environmental variables along forest edgeinterior gradient in fragmented forest patches of Taita Hills, Kenya. - Forest Ecology and Management 409: 789-798.

[40] Xue, B. L., Kumagai, T., Iida, S., Nakai, T., Matsumoto, K., Komatsu, H., Otsuki, K., Ohta, T. (2011): Influences of canopy structure and physiological traits on flux partitioning between understory and overstory in an eastern Siberian boreal larch forest. Ecol. Modell. 222: 1479-1490. 